\title{
Siçanlarda Ihlamur (Tilia platyphyllos Scop) İnfüzyonunun İmmün Sistem Üzerine Etkilerinin Araştırılması
}

\author{
Necati ÖZOK ${ }^{*}$, İsmail ÇELİK \\ ${ }^{1}$ Van Yüzüncü Yll Universitesi, Fen Fakültsi, Biyoloji Bölümö̈̈, Van \\ ${ }^{2}$ Van Yüzüncü Yll University, Fen Fakültsi, Moleküler Biyoloji ve Genetik Bölümü, Van \\ (ORCID: 0000-0002-6733-211X) (ORCID: 0000-0002-6330-754X)
}

\begin{abstract}
$\ddot{\mathbf{O} z}$
Çay olarak tüketilen en yaygın bitkilerden biri olan ıhlamur (Tilia platyphyllos Scop) bitki çiçek özellikle soğuk kış aylarında yoğun şekilde tüketilmektedir. Halk arasında, güçlü sakinleştirici etkisinin olduğu, iltihaplanmayı azalttığı, tansiyonun düşürülmesine destek olduğu, bağışıklık sistemini güçlendirdiği kabul edilmektedir.

Fakat hhlamur çayının kullanım süresi, sıklı̆g ve dozuna bağlı olarak canlılar üzerinde nasıl bir etkiye sahip olduğunu gösteren araştırmalar sınırlıdır. Bu çalışmada, sıçanlar her grupta altı adet sıçan bulunan dört gruba ayrıldı. Grup 1 [(kontrol grubu) (sadece musluk suyu)], grup 2 [(\%20 EtOH) (musluk suyu+\%20 etil alkol karışımı)], grup 3 [(LF) (musluk suyu+ \%2 ıhlamur çiçek infüzyon karışımı)], grup 4 [( EtOH +LF) (etil alkol+ $\% 2$ ihlamur çiçe $\mathrm{k}$ infüzyonu)] . Günlük hazırlanan içme suları ve karışımları 50 gün süreyle sıçanlara verildi. $\mathrm{Bu}$ çalışmada, EtOH'un immünotoksik etkilerine karşı LF infüzyonunun iyileştirici etkilerini ortaya koymak için sıçanlarda immün sistem biyobelirteçlerinden adenozin deaminaz (ADA) ve miyeloperoksidaz (MPO) aktiviteleri üzerine olası etkilerinin ölçülmesi amaçlanmıştır. Sonuç olarak, analiz dokularında ADA ve MPO aktivitesinin kontrol gruplarına göre önemli ölçüde arttığı belirlendi $(\mathrm{p}<0.05)$.
\end{abstract}

Anahtar kelimeler: ADA, Ihlamur, MPO, Sıçan, Tilia platyphyllos

\section{Investigation of the Effects of Linden (Tilia platyphyllos Scop) Infusion on Immune System in Rats}

\begin{abstract}
One of the most common plants consumed as tea, the linden (Tilia platyphyllos Scop) plant flowers are consumed extensively during the cold winter months. It is considered that it has a strong sedative effect, reduces inflammation, supports tension reduction, and strengthens the immune system. However, there are limited studies showing how linden tea has an effect on living beings due to the duration, frequency and dose of lime tea. In this study, rats were divided into four groups of six rats in each group. Group 1 [(control group) (only tap water was given)], group 2 [(20\% EtOH) (mixed water $+20 \%$ ethyl alcohol mixture)], group 3 [(LF) (tap water $+2 \%$ linden flower infusion mixture was given $)]$, group $4[(\mathrm{EtOH}+\mathrm{LF})($ ethyl alcohol $+2 \%$ linden flower infusion)]. Daily prepared drinking water and mixtures were given to rats for 50 days. The aim of this study was to determine the possible effects of adenosine deaminase (ADA) and myeloperoxidase (MPO) activities on immune system biomarkers in rats to demonstrate the therapeutic effects of LF infusion against the immunotoxic effects of EtOH. As a result, ADA and MPO activity were significantly increased in the control tissues compared to the control groups $(\mathrm{p}<0.05)$.
\end{abstract}

Keywords: ADA, Linden, MPO, Rat, Tilia platyphyllos

\section{Giriş}

İnsanlar binlerce yıldır, bitkisel ürünleri hastalıkların tedavisinde kullanmışlardır [1]. Tıbbın pek başarılı olmadığı bir kısım kronik hastalıkların tedavisinde de umut verici bir yöntem olarak

"Sorumlu yazar: necatiozok@yyu.edu.tr

Geliş Tarihi: 27.03.2019. Kabul Tarihi: 21.04.2019 
görülmüştür [2]. Ancak bitkiler ikincil toksik olabilecek metabolitler üreterek savunma mekanizmalarını oluştururlar [3]. Tedavi amaçlı bitki ürünlerinin giderek daha fazla kullanım süresi, sıklı̆̆ 1 ve dozuna bağlı neden olabileceği yan etkiler konusunda şüpheleri de beraberinde getirmektedir [4-5]. Bitkisel ürünlerdeki aktif bileşenlerden özellikle, alkaloitler, flavonoidler, terpenoidler ve saponinler gibi fitokimyasallar, memelilerde bir kısım toksik etkilerin gelişiminde rol oynar. Alkaloitler, nörotransmiter sistemlerinin agonisti veya antagonisti olarak davranır ve bu durumun engellenmesine neden olabilir [6]. Benzer şekilde, lipitte çözünen bazı terpenler, memeli kolinesterazına karşı inhibe edici özellikler göstermiştir [7]. Saponinler ise insan eritrositlerinin hücresel zarlarını etkileyerek hemolitik aktiviteye yol açarlar [8].

Tilia cinsi, çoğunlukla Avrupa ve Asya'da dağılmış, bir kaç cinsi de Kuzey Amerika'da bulunan 25-80 türden oluşur [9]. Halk hekimliğinde 1hlamur çiçeği sedative etkilerinin dışında diüretik, mide ağrısı ve spazmlar, gastroenterit, enterokolit, hepatik ve nefritik kolikleri tedavi etmek için yaygın şekilde kullanılmaktadır [10-11]. Ihlamur çiçeği \%3-10 polisakkarit olan musilaj, taninler (güçlü antioksidanlar) diğer fenolik bileşikler, başta başta kuersetin, kemferol glikozitleri ve fenolik asitler (kafeik, p-kumaratik ve izokuersetin) olmak üzere flavonoidlerdir [12]. Doğal olarak bulunan bu bileşiklerin birçoğu sahip oldukları antioksidatif etkileri ile hücresel bileşenleri oksidatif hasardan korumak ve hastalıkları önlemek olduğu bilinmektedir [13-14].

Buna ilaveten çok sayıda doğal bileşikler günümüzde fizyolojik fonksiyonlar ve biyotransformasyon reaksiyonlarda detoksifikasyon işleminde modulatör bir rölü olduğu kabul edilmektedir [15]. Ancak halk hekimleri ve bazı sağlı uzmanları bitkisel ilaçların "doğal" olduklarından nispeten güvenli olduğuna inanmalarına rağmen, bu varsayımı destekleyecek çok az veri vardır. Tıbbi amaçla kullanılan bitkilerin aynı zamanda ilaçlar gibi davranabildiği, oluşan kimyasal maddelerinde insanlarda biyolojik bir faaliyete sahip olduğu ileri sürülmüştür [16-17]. Günümüzde insanların hem besin maddesi olarak hem de tedavi amaçlı bitkisel doğal ürünlere karş1 artan yoğun ilgi ve kullanımları söz konusudur. Yapılan literatür araştırmalarında LF içecek ekstraktının subkronik uygulanmasının sıçanların immün sistemi üzerine olan etkilerini ortaya koyan herhangi bir çalışmaya rastlanılmamıştır. Dünyada alkol tüketilmesi gittikçe artmaktadır. Canlı üzerindeki toksik etkileri, karaciğerde yağlanmaya ve harabiyete sebep olduğu bilimsel çalışmalarla kanıtlanmıştır.

Bu çalışmada, ıhlamur çiçeği infüzyonunun etanolün immünotoksik etkilerine karşı iyileştirici etkilerini ortaya koyulması için sıçanlarda immün sistemin biyobelirteçlerden adenozin deaminaz ve miyeloperoksidaz aktiviteleri üzerine olası etkilerinin ölçülmesi amaçlanmıştır.

\section{Materyal ve Metot}

\subsection{Deney hayvanlar}

Bu çalışmada 4-5 aylık 200-250 gr ağırlığında erkek Sprague Dawley cinsi sıçanlar Yüzüncü Yıl Üniversitesi Deney Hayvanları Uygulama ve Araştırma Merkezi' nden (YÜDETAM, Van, Türkiye) temin edildi. Sıçanlar, yaklaşık $12 / 12$ saat aydınlık/karanlık peryodunda $21 \pm 1^{\circ} \mathrm{C}$ sıcaklıktaki ortamda tutuldu. Deney süresince musluk suyu ve standart pelet yem verildi.

\subsection{Bitki materyalı}

$\mathrm{Bu}$ çalışmada, fitoterapide kullanılan ıhlamur çiçeği, Çankırı/Türkiye'deki yerel bir pazardan satın alınmıştır. Bilimsel teşhisi Van Yüzüncü Yı1 Üniversitesi Biyoloji Bölümünde (Dr. Fazlı ÖZTÜRK) yapılmıştır. Seçilen bitki farklı hastalıkların tedavisi için pratikte kullanılmaktadır. Günlük kullanımında tıbbi reçeteye tabii değildir. Bitkisel infüzyon olarakda kullanılabilmektedir. Bitki örneği (No.164099) Van Yüzüncü Y1l Üniversitesi Fen Fakültesi Herbaryumu'nda (VANF) korunmuştur.

\subsection{Deneysel tasarım}

Siçanlar, her biri altı sıçan içeren dört gruba rastgele ayrıldı. I. Grup (Kontrol): Siçanlar musluk suyu içirildi ve ad libitum olarak standart pelet diyeti ile beslendi. II. Grup (EtOH): Siçanların içme sularına $\% 20$ etanol ilave edilerek ad libitum olarak standart pelet diyeti ile beslendi. III. Grup (LF) \%2 
1hlamur çiçeği ekstresi sıçanların içme sularına ilave edildi ve ağız yoluyla ad libitum olarak standart pellet diyeti ile beslendi. IV. Grup (EtOH+LF) sıçanların içme sularına \%2 1hlamur çiçeği ekstresi ve $\% 20 \mathrm{EtOH}$ ilave edildi. Ağız yoluyla adlibitum olarak standart pelet diyeti ile beslendi.

\subsection{Doku süpernatantların hazırlanması}

Deneysel uygulamanın sonunda sıçanlar ketaminle $(4 \mathrm{mg} / 100 \mathrm{~g} \mathrm{w} / \mathrm{v})$ intraperitonal yolla anestezi edildi. Dokular daha sonra fizyolojik su ile yıkand. Karaciğer, dalak, böbrek, beyin ve kalp dokusu (100 mg) 5 dakika $50 \mathrm{mM}$ buzda soğutulmuş fosfat $\left[\left(\mathrm{KH}_{2} \mathrm{PO}_{4}(1: 5 \mathrm{w} / \mathrm{v})\right]\right.$ tamponda $(\mathrm{pH} 7.4)$ homojenize edildi. Homojenatlar 9000 rpm'de 25 dakika boyunca $4^{\circ} \mathrm{C}$ santrifüj edildi (Hettich Universal 320R). Süpernatantlar sonra analizlerde kullanılmak için eppendorf tüplere alındı ve $-80{ }^{\circ} \mathrm{C}$ derecede derin dondurucuda muhafaza altına alındı [18-19].

\subsection{Biyokimyasal ölçümler}

\subsubsection{ADA aktivite ölçümü}

ADA aktivite tayini Giusti'ye göre yapıld1.Bu metoda gore ADA, adenozinden inozin (deoksiinozin) oluşumunu katalizlemektedir. Bu sırada açığa çıkan amonyak, sodyum hipoklorit ve fenol/nitroprussid ile birlikte alkali çözeltide koyu mavi indofenol oluşturur. Oluşan koyu mavi indofenol 630 nm'de kolormetrik olarak ölçüldü [20].

\subsubsection{MPO aktivite ölçümü}

MPO, Bradley ve arkadaşları tarafindan tarif edilen metoda göre yapıldı. Bu metod MPO tarafindan oksitlenen $\mathrm{H}_{2} \mathrm{O}_{2}$ 'nin, O-dianisidine redüklenmesi sonucunda oluşan ürünün $460 \mathrm{~nm}$ 'de absorbanslarının ölçülmesi esasına dayanmaktadır [21].

\section{6. İstatistiki Analiz}

İstatistiksel Analizler SPSS (Windows SPSS, Sürüm 23.0) paket programı kullanılarak gerçekleştirildi. Tüm veriler, ortalama \pm standart hata (SEM) olarak sunuldu. Deney gruplarının ortalamaları arasındaki farkları belirlemek için anlamlılık düzeyini $\mathrm{p} \leq 0,05$ olarak kabul eden One-way analysis of variance (ANOVA) istatistiksel test ve Tukey post-test kullanıld.

\section{Bulgular ve Tartışma}

Çalışma materyalinin 50 günlük uygulanmasının sonucunda, LF infüzyonunun EtOH kaynaklı oksidatif strese karşı immünsistem üzerine olan etkisi, imminolojik biyomarker enzimlerden ADA ve MPO enzim aktiviteleri karaciğer, dalak, kalp, böbrek ve beyin dokularında ölçülerek değerlendirildi (Tablo-1). Elde edilen sonuçlar göre karaciğer ADA enzim aktivitesi kontrol grubu ve EtOH grubu ile karşılaştırıldığında EtOH+LF grubunda anlamlı bir artış belirlendi, LF grubunda ise kontrol grubuna göre artarken EtOH grubuna göre ise aktivitede anlamlı bir azalma gözlendi $(p \leq 0,05)$. Dalak ADA enzim aktivitesi kontrol ve EtOH grubuna göre karşılaş̧ırıldığında, EtOH+LF ve LF grubunda anlamlı bir şekilde arttı̆̆ tespit edildi $(\mathrm{p} \leq 0,05)$. EtOH+LF uygulanan gruptaki kalp ADA aktivitesinin kontrol ve EtOH grubuna göre anlamlı bir arttı̆g belirlendi $(\mathrm{p} \leq 0,05)$. LF grubunda ise ADA aktivitesi kontrol grubuna göre anlamlı bir artış gösterdi $(\mathrm{p} \leq 0,05)$. Böbrek ADA aktivitesinin kontrol ve EtOH grubuna göre $\mathrm{EtOH}+\mathrm{LF}$ ve LF uygulanan grupta artış1 anlamlı bulundu $(\mathrm{p} \leq 0,05)$. Beyin ADA aktivitesi $\mathrm{EtOH}+\mathrm{LF}$ uygulanan gruplarında kontrol ve EtOH gruplarına göre artışı anlamlı bulundu $(p \leq 0,05)$. LF uygulanan grupta ise ADA enzim aktivitesi kontrol grubuna göre artarken $\mathrm{EtOH}+\mathrm{LF}$ uygulanan gruba göre ise azald $1(\mathrm{p} \leq 0,05)$.

Karaciğer MPO enzim aktivitesindeki artışı EtOH+LF ve LF uygulanan grupta kontrol grubuna göre anlamlı bulundu, anacak LF uygulanan grupta aktivite EtOH grubuna göre anlamlı bir azalış gösterdi $(\mathrm{p} \leq 0,05)$. Dalak MPO enzim aktivitesinin tüm uygulama gruplarında kontrol grubuna 
göre anlamlı arttığı belirlenirken, EtOH+LF grubunda ise artış EtOH grubuna göre anlamlı bulundu $(\mathrm{p} \leq 0,05)$. Kalp EtOH+LF grubu MPO enzim aktivite artış1 kontrol grubuna göre anlamlı bulunmazken( $\mathrm{p}>0,05)$, LF grubunda aktivite artışı kontrol ve EtOH grubuna göre anlamlı bulundu $(\mathrm{p} \leq 0,05) . \mathrm{EtOH}+\mathrm{LF}$ grubu böbrek MPO enzim aktivitesi artış1 kontrol grubuna göre, LF grubu MPO enzim aktivite artışı ise hem LF hemde EtOH grubuna göre anlamlı bulundu $(p \leq 0,05)$. Beyin MPO enzim aktivitesinde meydana gelen artış tüm uygulama gruplarında kontrol grubuna göre anlamlı bulundu $(\mathrm{p} \leq 0,05)$.

Tablo 1. Sıçanlarda EtOH'ün olası immünotoksik etkisine karşı ıhlamur çiçeği (Tilia platyphyllos) infüzyonunun iyileștirici etkileri

\begin{tabular}{llllll}
\hline Dokular & Parametreler & Kontrol & EtOH & EtOH +LF & LF \\
\hline Karaciğer & ADA (U/g) & $10.56 \pm 0.61$ & $16.16 \pm 0.10^{\mathrm{a}}$ & $17.68 \pm 0,84^{\mathrm{ab}}$ & $12.58 \pm 0.11^{\mathrm{ab}}$ \\
& MPO (U/g) & $168.78 \pm 2.20$ & $256.34 \pm 5.80^{\mathrm{a}}$ & $274.11 \pm 2.08^{\mathrm{ab}}$ & $181.21 \pm 4.76^{\mathrm{ab}}$ \\
Dalak & ADA (U/g) & $15.38 \pm 0.06$ & $21.25 \pm 0.06^{\mathrm{a}}$ & $24.04 \pm 0.04^{\mathrm{ab}}$ & $23.77 \pm 0.07^{\mathrm{ab}}$ \\
& MPO (U/g) & $1549.49 \pm 28.00$ & $3310.49 \pm 66.44^{\mathrm{a}}$ & $3634.51 \pm 68.04^{\mathrm{ab}}$ & $3160.74 \pm 57.72^{\mathrm{a}}$ \\
Kalp & ADA (U/g) & $7.61 \pm 0.08$ & $8.66 \pm 0.06^{\mathrm{a}}$ & $9.54 \pm 0.07^{\mathrm{ab}}$ & $8.66 \pm 0.14^{\mathrm{a}}$ \\
& MPO (U/g) & $565.99 \pm 18.32$ & $1001.69 \pm 15.37^{\mathrm{a}}$ & $689.34 \pm 13.83^{\mathrm{a}}$ & $929.44 \pm 18.33^{\mathrm{ab}}$ \\
Böbrek & ADA (U/g) & $12.86 \pm 0.07$ & $15.35 \pm 0,16^{\mathrm{a}}$ & $28.17 \pm 0.09^{\mathrm{ab}}$ & $16.22 \pm 0.10^{\mathrm{ab}}$ \\
& MPO (U/g) & $327.91 \pm 15.21$ & $619.16 \pm 13.22^{\mathrm{a}}$ & $613.77 \pm 20.76^{\mathrm{a}}$ & $917.95 \pm 21.49^{\mathrm{ab}}$ \\
Beyin & ADA (U/g) & $4.43 \pm 0.03$ & $6.41 \pm 0,04^{\mathrm{a}}$ & $7.68 \pm 0.06^{\mathrm{ab}}$ & $4.76 \pm 0.04^{\mathrm{ab}}$ \\
& MPO (U/g) & $117.59 \pm 10.82$ & $244.50 \pm 13.45^{\mathrm{a}}$ & $280.88 \pm 12.41^{\mathrm{a}}$ & $247.04 \pm 22.57^{\mathrm{a}}$ \\
\hline
\end{tabular}

Değerler ortalama ve standart hata olarak ifade etmektedir

${ }^{a}$ Kontrol grubu ile EtOH, EtOH+LF, LF grupları arasındaki fark anlamlıdır $(\mathrm{p} \leq 0.05)$.

${ }^{b} \mathrm{EtOH}$ grubu ile $\mathrm{EtOH}+\mathrm{LF}$, LF grupları arasındaki fark anlamlıdır $(\mathrm{p} \leq 0.05)$.

Sigara ve alkol kullanımının da artması özellikle kullanıcılarda serbest radikallerin oluşum hızının artmasına ve bununla birlikte antioksidan savunma sisteminin yetersizliği neticesinde çeşitli kronik hastalıklar meydana gelmektedir. Diyabet, kalp hastalıkları, hipertansiyon, sedef, romatoid artrit, kas, deri, göz hastalıkları, kanser ve yaşlılık gibi birçok hastalıkta serbest radikal ve lipit peroksidasyon ürünlerinin artması sonucunda antioksidan savunma mekanizmalarının yetersiz kaldığı gözlenmiştir. Ancak bu hastalıkların patogenezisinde reaktif oksijen türleri (ROS) artışı hastalığın sebebi mi yoksa bir sonucu mu olduğu kesin olarak bilinmemektedir. Bilinen odur ki; bu tür hastaların dokularında yoğun bir şekilde oksijenin mevcudiyetidir [22-23]. Deneysel çalışmalar da, serbest radikaller, lipid peroksidasyonu ve peroksidasyon ürünleri ile kanser gelişimi arasında pozitif bir ilişkinin söz konusu olduğu ortaya konulmuştur. Birçok kimyasal maddenin hücrede oksidatif stresi artırarak, kansere sebep olduğu bildirilmektedir. Bu maddeler SOD, GSH-Px ve katalaz aktiviteleri dâhil hücrenin antioksidan savunmasında ani ve sürekli bir azalmaya neden olmaktadır. Keza, fiziksel ajanlardan radyasyonun da serbest radikal ve lipid peroksidasyon üretimini artırarak kansere sebep olduğu gösterilmiştir. Serbest radikaller, kanserin başlangıç, ilerleme ve gelişme dönemlerinde etkili olmakla beraber bu etki ilerleme döneminde daha belirgin, diğer dönemlerde ise nispeten azdır. Serbest radikallerin etkisi sonucu DNA ve kromozomlarda kırılma ve onkogenlerde aktivasyonda artışa sebep olur [24].

ADA, insan vücudunun bağışıklık sisteminin normal çalışması için gereklidir. ADA pürin katabolize enzimlerin yüksek aktivitesi olan mekanizmanın ilk enzimi olarak kabul edildiği gibi organ ve hücrelerde adenozin konsantrasyonlarını kontrolünde anahtar bir enzim olarak da bilinir [25]. Dokularda anormal enzim seviyelerinin varlığı, klinik uygulamada doku hasarının ve hangi organın etkilendiğini göstermek için iyi bir indikatör olarak kabul edilir. ADA, adenozin'nin (Ado) yıkımından sorumlu enzim olduğundan, aktivitesinin inhibisyonu, stres koşulları altında dokularda Ado birikimesinin bir sonucu olarak kabul edilir. EtOH maruziyeti ile ilişkili mitokondriyel membran disfonksiyonu ATP metabolizmasını azaltır ve ADA'nın alt birimleri olan adenozin ve inozin gibi pürin yıkımı ürünlerinin artışına neden olur. ADA, hücrelerde toksik adenozin ve deoksiadenozine parçalayarak birikir. Bir enzimin sitotoksik etkileri, enzim eksikliğinden veya enzim substratının birikmesinden kaynaklanır. Mevcut çalışmada, kontrol grubuna göre EtOH ile LF+EtOH ve EtOH 
grubuna göre de LF+EtOH grubu karşılaştırılıdğında sıçanların karaciğer ve dalak dokusunda önemli derecede artmış ADA aktivitesinin kesin sebebi anlaşılmamakla beraber aşırı substrat artışı olan Ado üretiminden kaynaklanmış olabilir [26-27]. EtOH grubu LF grubuyla karşılaştıııldığında ise karaciğer ADA aktivitesinde önemli derecede düşüş gözlenmesi LF ekstraktının antioksidan etkisi ile ilişkili bu enzimin aktivitesinde nisbeten etkili olduğunu göstermiştir. Buna göre immün sistem fonksiyonları ile ilgili olan ADA enzim aktivitesinin azalması bu sistemi olumsuz yönden etkilemektedir. ADA'1n bağışıklık sistem fonksiyonlarıyla ilişkili olduğu ve immunitenin arttığı durumlarda aktivitesinin arttı̆̆ı, azaldığı durumlarda ise ADA aktivitesinin azaldı ̆̆ını bildirmiştir [28].

Myeloperoksidaz (MPO), agresif oksidanlar üretebilen önemli bir nötrofil enzimidir. Yapılan çalışmalar; karaciğer MPO seviyesinin artmasının karaciğer hasarıyla yakından ilişkili olduğunu rapor edilmiştir [29-30]. Çalışmamızda da artan MPO aktivitesi, karaciğer, dalak, kalp, böbrek ve beyin dokularında EtOH toksitesinin etkisi sonucu ROT üretiminin artışına bağlı gelişen hasarlarla ilişkili olduğu söylenebilir.

\section{Sonuç ve Öneriler}

$\mathrm{Bu}$ çalışmada, elde edilen biyokimyasal verilerin doğrultusunda etanolün sıçan karaciğerlerinde ve immün sisteminde meydana getirmiş olduğu tahribata bağlı olarak karaciğer harabiyet göstergesi olan MPO ve immün sistem biyobelirteci olan ADA enzimlerinin seviyelerinin arttı̆̆ gözlenmiştir. Bu enzim aktivitelerinde artış, etanol kaynaklı serbest radikal üretiminin artması ile ilişkili olabilir. Diğer yandan, 1hlamur çiçeği infüzyonu karaciğer ve immün sistem harabiyet göstergesi olan enzimlerini kontrollere yakın değere çektiği görülmüştür. Yine, etanolün neden olduğu oksidatif stres sonucu çeşitli dokularda dalgalanan biyobelirteçlerin etanol grubuna göre iyileştirme sağladığı tespit edilmiştir. Yapılan bir araştırmada, ıhlamurun kuersetin ve kempferol içeren bir bitki olduğu yapraklarında yüksek miktarda fenolik madde içerdiği rapor edilmiştir [31-32]. Bu çalışmanın, farklı dokular üzerinde etkilerinin gösterildiği ıhlamur infüzyonunun deney hayvanları üzerinde yapılacak in vivo çalışmalara 1şık tutacağı kanaatindeyiz.

\section{Teşekkür}

Bu çalışma Van Yüzüncü Y1l Üniversitesi Bilimsel Projeler Koordinasyon Başkanlığı tarafından (YYÜ-BAP-2010-FBE-YL002) desteklenmiştir.

\section{Kaynaklar}

[1] Kazi A., Urbizu D.A., Kuhn D.J., Acebo A.L., Jackson E.R., Greenfelder G.P., Dou Q.P. 2003. A natural musaceas plant extract inhibits proteasome activity and induces apoptosis selectively in human tumor and transformed, but not normal and non-transformed, cells. International journal of molecular medicine, 12 (6): 879-887.

[2] de Mel Y., Perera S., Ratnaweera P.B., Jayasinghe C.D. 2017. Novel insights of toxicological evaluation of herbal medicine: Human based toxicological assays. Asian Journal of Pharmacy and Pharmacology, 3 (2): 41-49.

[3] Rodriguez-Fragoso L., Reyes-Esparza J., Burchiel S.W., Herrera-Ruiz D., Torres E. 2008. Risks and benefits of commonly used herbal medicines in Mexico. Toxicology and applied pharmacology, 227 (1): 125-135.

[4] Anonymous World Health Organization. WHO Traditional Medicine Strategy 2002-2005. Geneva, World Health Organization, 2002. (document reference WHO/EDM/TRM/2002.1).

[5] Prakash A.S., Pereira T.N., Reilly P.E., Seawright A.A. 1999. Pyrrolizidine alkaloids in human diet. Mutation Research/Genetic Toxicology and Environmental Mutagenesis, 443 (12): 53-67.

[6] Ifeoma O., Oluwakanyinsola S. 2013. Screening of herbal medicines for potential toxicities. In New Insights into Toxicity and Drug Testing. Intech Open.

[7] Kennedy D.O., Wightman E.L. 2011. Herbal extracts and phytochemicals: plant secondary metabolites and the enhancement of human brain function. Advances in Nutrition, 2 (1): 3250 . 
[8] Navarro V.J., Barnhart H., Bonkovsky H.L., Davern T., Fontana R.J., Grant L., Stolz A. 2014. Liver injury from herbals and dietary supplements in the US Drug-Induced Liver Injury Network. Hepatology, 60 (4): 1399-1408.

[9] Buchbauer G., Remberg B., Jirovetz L., Nikiforov A. 1995. Comparative headspace analysis of living and fresh cut lime tree flowers (Tiliae flores). Flavour and Fragance Journal, 10: 221-224.

[10] Gülçin İ. 2009. Antioxidant activity of 1-adrenaline: A structure-activity insight. Chemicobiological interactions, 179 (2-3): 71-80.

[11] Tachjian A., Maria V., Jahangir A. 2010. Use of herbal products and potential interactions in patients with cardiovascular diseases. Journal of the American College of Cardiology, 55 (6): 515-525.

[12] Hardin J.W. 1990. Variation patterns and recognition of varieties of Tilia americana sl. Systematic botany, 33-48.

[13] Viola H., Wolfman C., Levi de Stein M., Wasowski C., Pena C., Medina J.H., Palad'ın A.C. 1994. Isolation of pharmacologically active benzodiazepine receptor ligands from Tilia tomentosa (Tiliaceae). Journal of Ethnopharmacology, 44: 47-53.

[14] Toker G., Aslan M., Yesilada E., Memisoglu M., Ito S. 2001. Comparative evaluation of the flavonoid content in officinal Tiliae flos and Turkish lime species for quality assessment. Journal of Pharmaceutical and Biomedical Analysis, 26: 111-121.

[15] Durak Z.E. 2013. Adenozin Deaminaz Enziminin Kinetik Davranışı Üzerine Zerdeçal (Curcuma longa) Ekstresinin Etkilerinin Araştırılması. Gazi Üniversitesi MühendislikMimarlık Fakültesi Dergisi, 28 (4).

[16] Pavón N.P. 2000. endangered and potentially economic tree of Mexico: Tilia mexicana (Tiliaceae). Economic botany, 54 (1): 113-114

[17] Matsuda H., Ninomiya K., Shimoda H., Yoshikawa M. 2002. Hepatoprotective principles from the flowers of Tilia argentea (Linden): structure requirement of tiliroside and mechanism of action. Bioorganic and Medicinal Chemistry, 10: 707-712.

[18] Xia E., Rao G., Remmen H.V., Heydari A.R., Richardson A. 1994. Activities of antioxidant enzymes in various tissues of male fischer 344 rats are altered by food restriction. J. Nutr., 125: 195-201.

[19] Marklund S.L. 1990. Expression of extracellular superoxide dismutase by human cell lines. Biochemical Journal: 266 (1): 213-219.

[20] Giusti G. 1974. Adenosine deaminase. In: Methods of Enzymatic Analysis. Ed: Bergmeyer, H.U. AcademicPress Inc., New York, USA, 20: 204-229.

[21] Bradley P.P., Priebat D.A., Christensen R.D., Rothstein G. 1982. Measurement of cutaneous inflammation: estimation of neutrophil content with an enzyme marker. Journal of Investigative Dermatology, 78 (3): 206-209.

[22] Halliwell B., Gutteridge M.C. 1990. Role of free radicals and catalytic metal ions in human disease An overview. Methods in Enzmology, 186: 1-85.

[23] Janssen Y.M.W., Houten B.V., Borm P.J.A., Mossmon B.T. 1993. Biology of disease, cell and tissue responses to oxidative damage. Lab. Invest., 69 (3): 261-274.

[24] Özdem S., Şadan G. 1994. Serbest oksijen radikallerinin oluşum ve klinik açıdan önemi. Ankara Üniversitesi, Tip Fak. Derg., 11 (1): 63-71.

[25] Cristalli G.S., Costanzi C., Lambertucci G., Lupidi S., Vittori R., Volpini E, Camaioni E. 2001. Adenosine deaminase: functional implications and different classes of inhibitors. Med Res Rev., 21: 105-128.

[26] Aguirre-Hernández E., Martínez A.L., González-Trujano M.E., Moreno J., Vibrans H., SotoHernández M. 2007. Pharmacological evaluation of the anxiolytic and sedative effects of Tilia americana L. var. mexicana in mice. Journal of ethnopharmacology, 109 (1): 140-145.

[27] Kennedy D.A., Seely D. 2010. Clinically based evidence of drug-herb interactions: a systematic review. Expert opinion on drug safety, 9 (1): 79-124.

[28] Valentine W.N., Paglia D.E., Tartaglia A.P., Gilsanz F. 1977. Hereditary hemolytic anemia with increased red cell adenosine deaminase (45-to 70-fold) and decreased adenosine triphosphate. Science, 195 (4280): 783-785. 
[29] Jordan W.K., March R., Houchin O.B., Popp E. 1959. Intracellular partition of purine deaminases in rodent brain. Journal of neurochemistry, 4 (2): 170-174.

[30] Saha P., Das S. 2003. Regulation of hazardous exposure by protective exposure: modulation of phase II detoxification and lipid peroxidation by Camellia sinensis and Swertia chirata. Teratogenesis, carcinogenesis, and mutagenesis, 23 (S1): 313-322.

[31] Atoui A.K., Mansouri A., Boskou G., Kefalas P., 2005. Tea and herbal infusions: Their antioksidant activity and phenolic profile, Food Chemistry, 89: 27-36.

[32] Karakaya S., El S.N. 1999. Quercetin, luteolin, apigenin and keampferol contents of some foods. Food Chemistry, 66: 289-292. 